\title{
PERSEPSI MENGENAI HUKUM PIDANA ADAT
}

Oleh :

\author{
Hj. UKILAH SUPRIATIN,S.H., M.H. dan IWAN SETIAWAN, S.H., M.H.*)
}

\begin{abstract}
Indonesian cultural heritage, embodied in various forms in the form of customs and traditions (intangible) that was revealed in the indigenous communities, it should be appreciated by researchers to better appreciate the meaning of cultural heritage. Which has the appeal of commodities cultural tourism Criminal Law Customary law is not written or written have had the sense sanksi.Hukum Criminal offense Indigenous Peoples, several indigenous offense, the nature of the offense Customary law, traditional way of solving a crime.
\end{abstract}

\begin{abstract}
ABSTRAK
Warisan budaya Indonesia, yang tertuang dalam berbagai bentuk baik berupa adat istiadat maupun tradisi (intangible) yang terungkap dalam masyarakat adat, sudah selayaknya diapresiasi oleh peneliti agar lebih mampu menghayati makna warisan budaya tersebut. Yang memiliki daya tarik komoditi wisata budaya Hukum Pidana Adat merupakan hukum yang tidak tertulis maupun tertulis yang memiliki sanksi.Hukum Pidana Adat memiliki pengertian delik Adat, beberapa delik adat, sifat hukum delik Adat, cara penyelesaian delik adat.
\end{abstract}

\footnotetext{
*) Dosen Fakultas Hukum Universitas Galuh
} 


\section{Pendahuluan}

Indonesia merupakan suatu negara yang memiliki wilayah laut yang paling besar di dunia, terdiri dari ribuan pulau, baik pulau besar maupun pulau kecil Identitas Kelautan Indonesia. Negara Kepulauan Fakta geografis wilayah Indonesia, Negara Kelautan Fakta biofisik, 70\% wilayah adalah laut, Negara Maritim Pengelolaan laut untuk kepentingan bangsa Indonesia total luas laut : 5,8 (5,9) jt km², Luas laut teritorial: 3,1 jt km2 Luas ZEE Indonesia : 2,7 (2,9) jt $\mathrm{km}^{2}$, Luas daratan : 1,89 jt km²,Panjang garis pantai : $95.181 \mathrm{~km}$,Jumlah pulau: 17.000 (13.466) (Zainal Arifin,2-3:2015).

Satjipto Rahardjo menulis bahwa sebelum Belanda, dan dengan demikian berbagai institut yang dibawanya, masuk di Indonesia di abad ketujuh belas, negeri ini sudah mengenal tatanan sosial dan kehidupan yang telah berkembang, Belanda tidak menemukan suatu komunitas yang primitif, melainkan berbagai kerajaan dan karya-karya budaya fisik maupun non fisik yang terkadang berkualitas dunia, seperti candi Borobudur. (Satjipto Rahardjo,48 :2008).

Warisan budaya Indonesia, yang tertuang dalam berbagai bentuk baik berupa adat istiadat maupun tradisi (intangible) yang terungkap dalam masyarakat adat, sudah selayaknya diapresiasi oleh peneliti agar lebih mampu menghayati makna warisan budaya tersebut. Yang memiliki daya tarik komoditi wisata budaya.

Pemberian makna kepada berbagai bentuk warisan budaya adalah suatu upaya pemahaman terhadap bagaimana masyarakat masa lalu memandang dan memperlakukan tradisi leluhur. Dalam teori kebudayaan yang menyatakan bahwa kebudayaan itu berada di antara masyarakat, merupakan pandangan semiotika. Semiotika dalam arkeologi merupakan salah satu kajian arkeologi kognitif, yang mengkaji sistem symbol dari suatu masyarakat.

Manusia sejak lahir dikaruniai naluri, sehingga atas dasar pikiran, perasaan dan kehendak maka timbul kemauan untuk bergaul dan menghasilkan interaksi sosial yang dinamis, yang secara sosiologis dapat membentuk perilaku manusia tertentu yang menghasilkan sesuatu yang disebut CARA. Dimana CARA dapat menghasilkan suatu tingkah laku dalam bentuk tertentu yang disebut dengan KEBIASAAN (FOLK WAYS). 
Dikalangan masyarakat umum istilah hukum adat jarang digunakan yang banyak dibicarakan ialah istilah adat saja. Menyebut kata adat maka masyarakat umum menyebutnya kebiasaan yang pada umumnya berlaku dalam masyarakat. Hukum pidana adat adalah hukum yang hidup di masyarakat dan akan terus hidup selama manusia ada dan budaya budaya di masyarakat terus berkembang sesuai jamannya.

Untuk itu perlu dikaji dan diteliti terus menerus mengenai perkembangan masyarakat dan hukum adat bukan hanya sebagai warisan budaya saja melainkan hukum yang hidup dan berkembang di masyarakat Indonesia.

\section{Pembahasan}

Secara tradisional definisi Hukum Pidana adalah hukum yang memuat peraturan peraturan yang mengandung keharusan dan larangan terhadap pelanggar mana diancam dengan hukuman yang berupa siksaan badan.(Samidjo, 10 : 1985) Menurut Moeljatno, mengartikan hukum pidana sebagai bagian dari keseluruhan hukum yang berlaku di suatu negara yang mengadakan dasar-dasar dan aturan-aturan untuk :

1. Menentukan perbuatan-perbuatan mana yang tidak boleh dilakukan, yang dilarang, dengan disertai ancaman atau sanksi pidana tertentu bagi siapa saja yang melanggarnya.

2. Menentukan kapan dan dalam hal apa kepada mereka yang telah melakukan larangan-larangan itu dapat dikenakan atau dijatuhi pidana sebagaimana yang telah diancamkan.

3. Menentukan dengan cara bagaimana pengenaan pidana itu dapat dilaksanakan apabila orang yang diduga telah melanggar ketentuan tersebut.( Moeljatno,1: 2008).

Menurut Hukum Pidana memuat aturan-aturan hukum yang mengaitkan kepada peraturan-peraturan yang memenuhi syarat tertentu suatu akibat yang berupa pidana. Berpokok pada dua hal, yaitu :

1. Memuat pelukisan-pelukisan dari perbuatan-perbuatan yang diancam pidana, yang memungkinkan pengadilan menjatuhkan pidana. Jadi di sini seolah-olah negara menyatakan kepada umum dan juga kepada para penegak hukum, perbuatan-perbuatan apa yang dilarang dan siapa yang dapat di pidana. 
2. KUHP menetapkan dan mengumumkan reaksi apa yang akan diterima oleh orang yang melakukan perbuatan-perbuatan yang dilarang itu. Dalam hukum pidana modern reaksi ini tidak hanya berupa pidana akan tetapi juga apa yang disebut dengan tindakan, yang bertujuan untuk melindungi masyarakat dari perbuatan-perbuatan yang merugikan. (Sudarto 100-101: 1977).

Menurut Satochid Kartanegara, Hukum Pidana adalah sejumlah peraturan-peraturan yang merupakan bagian dari hukum positif yang mengandung larangan-larangan dan keharusan-keharusan yang ditentukan oleh negara atau kekuasaan lain yang berwenang untuk menentukan peraturanperaturan pidana, larangan atau keharusan mana disertai ancaman pidana, dan apabila hal ini dilanggar timbul hak dari negara untuk melakukan tuntutan, menjalankan pidana, dan melaksanakan pidana.

Berdasarkan uraian tentang pengertian hukum pidana oleh para ahli diatas penulis menyimpulkan bahwa hukum pidana itu merupakan hukum sanksi baik sanksi materiil maupun sanksi formil.

Beberapa pandangan tentang hukum Adat. Adat dalam arti sopan santun adalah merupakan tingkah laku yang oleh adat akan, sedang, telah diadatkan (mendapat pengakuan umum dalam masyarakat). Dalam arti hukum adalah merupakan peraturan tingkah laku manusia yang bersumber kepada kesusilaan atau peraturan yang mengatur pergaulan hidup manusia yang merupakan endapan kesusilaan.

Adat dalam arti sopan santun ataupun dalam arti hukum, pemeliharaannya diserahkan kepada kebebasan pribadi yang diberikan ancaman hukuman antara lain berupa keluarga dari anggota kemasyarakatan masyarakat yang bersangkutan.

Di lihat dari uraian tadi maka hukum adat pengertiannya tergantung pada hati nurani rakyat (keadaan masyarakat lingkungan adat yang bersangkutan kecuali pengertian menurut para Sarjana).Istilah Hukum Adat Merupakan terjemahan dari Bahasa Belanda yaitu "Adat Rechts". istilah ini pertama kali merupakan suatu sistem pengendalian sosial (social control) maksudnya merupakan sistem yang ada dan hidup dalam masyarakat Indonesia. Yang menamakan adat recht sebagai social control ialah Snouchk Hurgronge dalam bukunya (Djarin Saragih S; 1894). 
Sebelum istilah adat rechts sebagai social control, istilah ini dipakai dalam perundang-undangan Hindia Belanda yaitu dalam :

a. AB (Algemene Van Wet Geving)

Dalam pasal $11 \mathrm{AB}$ istilah yang dipakai : "Goedientige Wetten, Volks Instellingen, en Gebruiken".

b. Regeling Reglement

Pasal 75 ayat (3) : "Goedentige Wetten, Instellingen, en Gebruiken".

Pasal 78 ayat (2) :"Ouder her Komsten"

c. IS (Indische Staat Regelings)

Pasal 134 ayat (2) : Adat Recht

Pasal 128 ayat (4) : Instellingen des Volks

Pasal 131 ayat (2) sub b : Met Hunne Goedientige Wetten en Stellingen Samen Hagede Recht Regelen.

Pengertian Hukum Adat menurut Sarjana-Sarjana Barat dan SarjanaSarjana Indonesia.

1. Van Vollen Hoven

Hukum Adat adalah hukum yang tidak bersumber kepada peraturan-peraturan yang dibuat oleh pemerintah Hindia Belanda dahulu.

2. J.H.P. Bellefroid

Hukum Adat sebagai peraturan-peraturan yang hidup yang meskipun tidak diundangkan oleh penguasa, dihormati dan di taati oleh rakyat dengan keyakinan bahwasannya peraturan tersebut berlaku sebagai hukum.

3. Roedolf Van Dijk

Hukum Adat merupakan istilah untuk menunjukkan hukum yang tidak dikodifikasikan dikalangan orang Indonesia asli dan Timur Asing.

4. Terr Haar

Hukum Adat :

a. Lahir dan dipelihara oleh keputusan-keputusan para warga masyarakat hukum terutama keputusan yang berwibawa dari kepala-kepala rakyat.

b. Hukum Adat mengabaikan bagian-bagian yang tertulis yakni terdiri dari peraturan-peraturan desa. 
Pengertian Sarjana-Sarjana Indonesia adalah sebagai berikut :

\section{R. Soepomo}

Hukum Adat adalah sebagai hukum yang tidak tertulis di dalam peraturanperaturan legislative meliputi peraturan-peraturan hidup yang meskipun tidak ditetapkan oleh yang berwajib, ditaati dan didukung oleh rakyat berdasarkan atas keyakinan bahwasannya peraturan tersebut mempunyai kekuatan hukum.

2. Soekanto

Hukum Adat adalah sebagai kompleks adat yang kebanyakan tidak dikitabkan, tidak dikodifisir dan bersifat paksaan, mempunyai sanksi, mempunyai akibat hukum.

3. Kusumadi Pudjo Soewojo

Hukum Adat adalah keseluruhan aturan hukum yang tidak tertulis.

4. Djojodiguno

Hukum Adat adalah hukum yang tidak bersumber kepada peraturanperaturan.

5. Hazairin

Hukum Adat adalah terutama hukum yang mengatur tingkah laku manusia Indonesia dalam hubungannya satu sama lain baik yang merupakan keseluruhan kelaziman, kebiasaan, dan kesusilaan yang benar-benar hidup dalam masyarakat. (Hazairin: 4-5 : 2015).

Apabila disimpulkan pendapat-pendapat tersebut Hukum adat merupakan suatu kompleks norma-norma yang bersumber kepada perasaan keadilan rakyat, yang selalu berkembang serta meliputi peraturan-peraturan tingkah laku manusia dalam kehidupan sehari-hari dalam masyarakat, sebagian besar tidak tertulis, senantiasa dihormati dan ditaati karena mempunyai akibat hukum (sanksi).

Hukum Pidana Adat atau hukum pidana yang tidak tertulis dalam bahasa Belanda dikenal sebagai ongeschreven strafrecht. (E Utrech 7 : 1994) Menurut Soerojo Wignjodipuro diantara bidang hukum adat, hukum pidana adat adalah bidang hukum adat yang eksistensinya terdesak oleh keberadaan hukum kolonial (Soerojo Wignjodipuro,18 : 1982). Beberapa sarjana kemudian memberikan pengertian mengenai hukum pidana adat untuk dapat memberikan pemahaman lebih lanjut, yang tentunya berpijak pada karakteristik hukum pidana pada umumnya. Van Vollenhoven mengartikan delik 
adat sebagai perbuatan yang tidak diperbolehkan. (Soerojo Wignjodipuro, Ibid: 228). Murid Van Vollenhoven, Ter Haar, kemudian mengartikan suatu delik sebagai setiap gangguan segi satu terhadap keseimbangan dan setiap penubrukan dari segi satu pada barang-barang kehidupannya materiil dan imateriil orang seorang atau dari pada orang-orang banyak yang merupakan satu kesatuan (segerombolan), tindakan sedemikian itu menimbulkan suatu reaksi yang sifatnya dan besar kecilnya ditetapkan oleh hukum adat ialah reaksi adat (adat reactie), karena reaksi mana keseimbangan dapat dan harus dipulihkan kembali (kebanyakan dengan jalan pembayaran pelanggaran berupa barang-barang atau uang).( Mr.B.Ter Haar Bzn 1981)

Hukum Pidana Adat adalah Hukum Indonesia asli yang tidak tertulis dalam bentuk perundang-undangan yang disana-sini mengandung unsur agama,ditakuti dan ditaati oleh masyarakat secara terus menerus,dari satu generasi ke generasi berikutnya.(I Made Widnyana 111:2013 ).Sedangkan pengertian Hukum Pidana Adat menurut Hilman Hadikusumah Hukum pidana adat disebut juga Hukum Adat Delik (adatdelicten recht) atau Hukum pelangaran Adat ialah aturan-aturan hukum yang mengatur peristiwa atau perbuatan kesalahan yang berakibat tergangunya keseimbangan masyarakat sehingga perlu diselesaikan (dihukum) agar keseimbangan masyarakat tidak terganggu.( Hilman Hadikusumah 230: 2003 ).

I Made Widyana menjelaskan mengenai pengertian Hukum Pidana Adat yang mengutip dari Hilman Hadikusumah adalah Hukum yang menunjukan peristiwa dan perbuatan yang harus di selesaikan (di hukum ) dikarenakan peristiwa dan perbuatan itu menganggu keseimbangan masyarakat.Jadi berbeda dengan hukum pidana barat yang menekankan peristiwa apa yang dapat diancam dengan hukuman serta macam apa hukumnya,dikarenakan peristiwa itu bertentangan dengan perundang-undangan.(I Made Widyana opcit 112).

I Made widyana juga menjalaskan bahwa yang dimaksud hukum pidana adat yaitu Hukum pidana adat mempunyai sumber hukumnya,baik yang tertulis maupun yang tidak tertulis.Sumber hukum yang tidak tertulis adalah kebiasaankebiasaan yang timbul,diikuti dan ditaati secara terus menerus dan turun temurun oleh masyarakat adat yang bersangkutan.Sedangkan sumber tertulis dari Hukum Pidana Adat adalah semua peraturan-peraturan yang dituliskan baik 
diatas daun lontar,kulit atau bahan lainnya.( I Made Widyana ibid 114) perbedaan mendasar antara delik adat dan hukum pidana (strafrecht) adalah telah ditentukannya perbuatan terlarang berikut sanksinya dalam undang- undang, sementara dalam hukum adat perbuatan yang dilarang berikut sanksinya tidak ditentukan lebih dahulu. Jadi, bentuk perbuatan dan sanksinya tidak statis. ( Anto Soemarman 55 :2003)

Hukum pidana dalam konteks hukum pidana adat yang dipaparkan Ter Haar menurut konsepsi hukum adat, apabila terjadi perbuatan pelanggaran terhadap ketentuan norma adat, maka sanksi adat yang pada hakekatnya merupakan reaksi adat, isinya bukanlah berupa siksaan atau penderitaan (leed) tetapi yang terutama adalah untuk mengembalikan kosmisch, yang terganggu sebagai akibat adanya pelanggaran. Seperti halnya Soepomo memberikan pengertian yang singkat mengenai hukum pidana adat, menurutnya segala perbuatan yang bertentangan dengan peraturan hukum adat merupakan perbuatan ilegal dan hukum adat mengenal pula ikhtiar-ikhtiar untuk memperbaiki kembali hukum ("rechtsherstei") (Soepomo.110:1982)

Hukum Pidana Adat memiliki pengertian delik Adat, beberapa delik adat, sifat hukum delik Adat, cara penyelesaian delik adat, menurut ahli yaitu : pengertian delik adat berdasarkan penjelasan Hilman Hadikusumah yang dikutip dari Van Vollenhoven delik adat adalah perbuatan yang tidak boleh dilakukan. Waluapun pada kenyataannya peristiwa atau perbuatan itu hanya sumbang (kesalahan ) kecil saja. Menurut Ter Haar delik ( pelanggaran ) itu ialah setiap gangguan dari suatu pihak atau dari sekelompok orang berwujud atau tidak berwujud, berakibat menimbulkan reaksi (yang besar kecilnya menurut ketentuan adat), suatu reaksi adat dan dikarenakan adanya reaksi itu maka keseimbangan harus dapat dipulihkan kembali / dengan pembayaran uang atau barang. (Hilman Hadikusumah, 23 :2003).

Jadi yang dimaksud delik adat adalah peristiwa atau perbuatan masyarakat yang mengganggu masyarakat lain sehingga menibulkan reaksi dari masyarakat. Peristiwa atau perbuatan yang berwujud atau tidak berwujud adalah perbutan manusia atau perbuatan yang gaib.

Hilman Hadikusumah menjelaskan mengenai keseimbangan masyarakat desa adalah apabila dalam masyarakat desa, masyarakat menjadi terganggu keseimbangan dikarenakan timbulnya banyak penyakit, tidak tenteram, selalu 
timbul kericuhan keluarga, maka masyarakat desa melakukan meruat desa atau bersih desa dengan upacara adat dengan memohon kepada Tuhan Yang Maha Kuasa agar keseimbangan masyarakat tidak terus menerus terganggu. Apabila keseimbangan yang terganggu itu akibat peristiwa atau perbuatan perorangan maka yang bersalah itu dikenakan hukum adat mengembalikan keseimbangan masyarakat. (Hilman Hadikusuma, 231 : 2003)

Sifat delik adat menurut Hilman Hadikusuma, beliau mengemukakan bahwa aturan-aturan hukum menurut pelanggaran adat pada umumnya bersifat sebagai berikut :

1. Tradisional magis religieus

Artinya perbuatan yang tidak boleh dilakukan dan perbuatan mana mengganggu keseimbangan masyarakat itu bersifat turun temurun dan dikaitkan dengan keagamaan.

Peristiwa atau perbuatan pelanggaran adat itu menurut alam pikiran yang tradisional banyak yang tidak rasional, tidak intelektual dan tidak liberal melainkan bersifat kosmis, menempatkan kehidupan umat manusia itu bertautan dengan alam, tidak terlepas dari ancaman Tuhan Yang Maha Pencipta.

2. Menyeluruh dan menyatukan

Peristiwa atau perbuatan delik adat itu bersifat menyeluruh dan menyatukan, artinya tidak memisah-misah antara delik yang bersifat pidana atau bersifat perdata, begitupula tidak dibedakan antara kejahatan sebagai delik hukum dan pelanggaran sebagai delik Undang-Undang. Begitu juga tidak dibedakan apakah delik itu merupakan perbuatan yang disengaja (opzet) atau karena kelalaian (culpa). Kesemuanya bersifat menyeluruh dan disatukan dalam cara menyelesaikannya sehingga tidak juga dibedakan antara pelaku (dader), dengan yang turut melakukan (mededader), atau yang membantu melakukan (medeplichtiger) atau yang menghasut (uitloker). Kesemuanya disatukan jika diantara yang satu dengan yang lainnya merupakan rangkaian peristiwa yang bersifat mengganggu keseimbangan, dan keseluruhannya dijadikan satu dalam penyelesainnya dihadapan peradilan (permusyawaratan para petugas hukum adat). 


\section{Tidak Prae-Existente}

Hukum Adat delik menurut Soepomo dalam Hilman Hadikusuma tidak menganut sistem prae-existante regels, tidak seperti hukum pidana barat sebagai dinyatakan dalam pasal 1 KUHP yang menganut adagium montesquieu yang berbunyi "Nullum delictum, nulla poena sine praevia lege poenall' (tiada suatu delik melainkan atas kekuatan aturan pidana di dalam undang-undang yang telah ada lebih dulu dari perbuatan itu). Artinya bahwa delik hukum pidana adat tidak menganut azas tersebut di atas.

4. Tidak menyama-ratakan

Apabila terjadi delik adat maka yang terutama diperhatikan ialah timbulnya reaksi atau koreksi dan terganggunya keseimbangan masyarakat, serta siapa pelaku perbuatan delik itu dan apa latar belakangnya. Terhadap pelaku delik hukum adat tidak menyama-ratakan, begitu pula peristiwa dan perbuatannya.

\section{Terbuka dan lentur}

Aturan hukum adat delik bersifat terbuka dan lentur (flexible) terhadap unsurunsur yang baru yang berubah, baik yang datang dari luar ataupun karena perubahan dan perkembangan masyarakat lingkungannya. Hukum adat tidak menolak perubahan-perubahan itu asal tidak bertentangan dengan kesadaran hukum dan keagamaan masyarakat bersangkutan.

6. Terjadinya delik adat

Terjadinya delik adat apabila tata tertib adat setempat dilanggar, atau dikarenakan adanya suatu pihak merasa dirugikan, sehingga timbul reaksi dan koreksi dan keseimbangan masyarakat menjadi terganggu. Misalnya perbuatan mencuri buah-buahan di Aceh jika pelakunya memetik buahbuahan itu dari pohon yang tidak dipelihara maka si pencuri dihukum membayar harganya.

Jika delik adat itu terjadi, tetapi masyarakat setempat tidak lagi merasa terganggu keseimbangannya, sehingga tidak ada reaksi atau koreksi terhadap si pelaku, maka perbuatan itu bukan lagi delik adat atau delik adat yang tidak mempunyai akibat hukum,. Kemudian delik-delik adat itu berbeda antara daerah yang satu dan daerah yang lain. 
7. Delik Aduan

Apabila terjadi delik adat, yang akibatnya mengganggu keseimbangan keluarga, maka untuk menyelesaikan tuntutan atau gugatan dari pihak yang dirugikan harus ada pengaduan, harus ada pemberitahuan dan permintaan untuk diselesaikan kepada kepala adat.

8. Reaksi dan Koreksi

Tujuan adanya tindakan reaksi dan koreksi terhadap peristiwa atau perbuatan delik adalah untuk memulihkan kembali keseimbangan masyarakat yang terganggu. Terhadap peristiwa atau perbuatan delik yang mengganggu keseimbangan masyarakat adat pada umumnya dilakukan oleh para petugas adat, sedangkan yang mengganggu pribadi atau keluarga adat dilaksanakan oleh kepala keluarga atau kepala kerabat bersangkutan. Begitu pula pertanggungjawaban kesalahannya dapat dikenakan kepada pribadi pelakunya atau keluarganya atau kepala adat.

9. Pertanggungjawaban Kesalahan

Menurut hukum pidana (delik adat) apabila terjadi peristiwa atau perbuatan delik yang dipersalahkan bagaimana akibat perbuatan itu dan siapa yang harus dimintai pertanggungjawaban. Sedangkan menurut hukum adat bukan saja pribadi pelakunya dapat dimintakan pertanggungjawaban tetapi juga keluarga atau kerabat dan/atau kepala adatnya.

Jadi menurut penulis pertanggungjawaban kesalahan hukum pidana adat ditanggung oleh keluarga, kerabat dan/atau kepala adatnya.

10. Tempat Berlakunya

Tempat berlakunya hukum delik adat tidak bersifat nasional tetapi terbatas pada lingkungan masyarakat adat tertentu atau di pedesaan. (Hilman Hadikusuma, ibid : 2013)

Hilman Hadikusuma juga mengemukakan beberapa delik adat, menurut beliau mengenai macam-macam delik adat pada setiap daerah memiliki delik adat yang berbeda-beda, adapun rinciannya adalah sebagai berikut :

1. Kesalahan mengganggu keamanan, antara lain kebakaran, perampokan, kerusuhan, pembunuhan, pertikaian, penganiayaan, pencurian, menemukan barang.

2. Kesalahan mengganggu ketertiban 
a. Kesalahan tata tertib masyarakat diantaranya karena senjata, mengganggu rumah, mengganggu ibadah, terhadap mayit dan bangkai, berjudi dan makanan haram, penghinaan.

b. Kesalahan tata tertib pemerintah diantaranya gawe raja, martabat, jabatan, kewargaan adat, kependudukan, adat perlengkapan dan harta adat.

c. Kesalahanaa kesopanan dan kesusilaan, sopan santun, bujang gadis dan wanita memegang, menangkap wanita, sembambangan, acara perkawinan, terhadap istri orang, berjinah atau sumbang.

d. Kesalahan dalam perjanjian, perjanjian tidak terlarang, mungkir janji, merusak perjanjian, pinjam meminjam, utang piutang atau gadai, amanat atau titipan.

e. Kesalahan menyangkut tanah, tanaman tumbuhan dan hasil hutan.

f. Kesalahana menyangkut hewan ternak dan perikanan. Diantaranya hewan ternak, penyembelihan hewan, hasil-hasil hutan.(Hilman Hadikusuma, Ibid : 238)

Penyelesaian delik adat yang berakibat terganggunya keseimbangan keluarga atau masyarakat Hilman Hadikusuma menyebutkan cara penyelesaian yang dilakukan karena terjadinya delik adat yaitu :

a. Penyelesaian antar pribadi, keluarga, tetangga

Jika terjadi suatu peristiwa atau perbuatan delik adat di tempat pekerjaan, dan lainnya maka untuk memulihkan gangguan keseimbangan keluarga atau masyarakat bersangkutan diselesaikan langsung ditempat kejadian antara pribadi bersangkutan atau diselesaikan di rumah keluarga salah satu pihak antara keluarga bersangkutan, atau di tempat pekerjaan oleh para pihak bersangkutan dan teman-teman sekerja, atau antara tetangga dalam kesatuan rukun tetangga.

b. Penyelesaian Kepala Kerabat atau Kepala Adat

Adakalanya pertemuan yang diselenggarakan pribadi, keluarga atau tetangga tersebut tidak mencapai kesepakatan atau karena suatu dan lain hal tidak berkelanjutan, sehingga perkaranya perlu dilanjutkan kepada Kepala Kerabat atau Kepala Adat dari kedua pihak maka yang mengadakan pertemuan selanjutnya adalah diantara kepala kerabat atau kepala adat. 


\section{c. Penyelesaian Kepala Desa}

Apabila penyelesaian delik adat dilakukan oleh kepala kerabat atau kepala adat kebanyakan menyangkut perselisihan khusus dikalangan masyarakat adat kekerabatan yang tidak termasuk kewenangan kepala desa, atau juga yang masih berlaku di masyarakat yang susunannya dengan kelompok suku-suku maka penyelesaian delik adat dari masyarakat yang bersifat ketetanggaan atau yang penduduknya campuran dilaksanakan kepala desa.

d. Penyelesaian Keorganisasian

Di kota-kota kecil atau besar atau daerah mana penduduknya heterogen dimana terdapat berbagai kumpulan atau organisasi kemasyarakatan yang mempunyai susunan pengurus dan keanggotaan seperti halnya perkumpulan-perkumpulan keluarga masyarakat adat di perantauan, perkumpulan kepemudaan dan kewanitaan, perkumpulan keagamaan lainnya, juga dapat melaksanakan penyelesaian secara kekeluargaan terhadap peristiwa atau perbuatan delik yang terjadi yang telah mengakibatkan terganggunya keseimbangan dalam kesatuan perkumpulan organisasi bersangkutan.

\section{Kesimpulan}

Hukum Pidana Adat merupakan hukum yang tidak tertulis maupun tertulis yang memiliki sanksi.Hukum Pidana Adat memiliki pengertian delik Adat, beberapa delik adat, sifat hukum delik Adat, cara penyelesaian delik adat, Delik Adat adalah perbuatan yang tidak boleh dilakukan, Sifat delik adat diantaranya Tradisional magis religieus, Menyeluruh dan menyatukan, Tidak Prae-Existente, Tidak menyama-ratakan, Terbuka dan lentur, Terjadinya delik adat, Delik Aduan, Reaksi dan Koreksi, Pertanggungjawaban Kesalahan, Tempat Berlakunya,macam-macam Delik Adat diantaranya, Kesalahan mengganggu keamanan, Kesalahan mengganggu ketertiban,Cara Penyelesian delik Adat Penyelesaian antar pribadi, keluarga, tetangga, Penyelesaian Kepala Kerabat atau Kepala Adat, Penyelesaian Kepala Desa, Penyelesaian Keorganisasian 


\section{Daftar Pustaka}

E Utrech. Rangkaian Sari Kuliah Hukum Pidana I. Surabaya. Pustaka Tinta Mas. 1994.

Hilman Hadikusumah, Pengantar Hukum Adat Indonesia, Bandung, Mandar Maju, 2003.

I Made Widnyana, Hukum Pidana Adat Dalam Pembaharuan Hukum Pidana, Jakarta Fikahati Aneska, 2013.

Moeljatno, Azas-azas Hukum Pidana, Cetakan Kedelapan, Edisi Revisi, Renika Cipta, Jakarta, 2008.

Mr. B. Ter Haar Bzn, Asas-asas dan Susunan Hukum Adat (Beginselen en stelsel van Adatrecht). Jakarta Pradnya Paramita : 1981. Terjemahan K.Ng. Soebakti Poesponoto.

Satjipto Rahardjo, Negara Hukum yang Membahagiakan Rakyatnya. Yogyakarta. Genta Press. 2008.

Samidjo, Ringkasan dan Tanya Jawab Hukum Pidana, Cv. Armico, 1985.

Sudarto: Hukum dan Hukum Pidana, Alumni, Bandung, 1977

Soerojo Wignjodipuro, Pengantar dan Asas-asas Hukum Adat. Jakarta. Gunung Agung.1982.

Soepomo. Bab-bab Tentang Hukum Adat. Jakarta. Pradnya Paramita.1982.

Ukilah Supriyatin Adat Istiadat Masyarakat Kampung Naga Merupakan Salah Satu Sumber Hukum Adat Sumber Hukum Adat Laporan Hasil Penelitian Fakultas Hukum Universitas Galuh 2014.

Diktat Hukum Adat Fakultas Hukum Universitas Galuh 2015.

Zainal Arifin, Sumber Daya Laut Indonesia Lokakarya Kelautan Nasional 2015 Mewujudkan Indonesia sbg Poros Maritim Dunia Fakultas Hukum Universitas Padjadjaran Bandung 9-10 Juni 2015. 